\title{
Comparison of biological markers in aerosol-weighed workplaces
}

\author{
Ilona Pavlovska (D) - Žanna Martinsone • \\ Anna Ramata-Stunda • Ivars Vanadziņš • \\ Inese Mārtinssone • Anita Seile
}

Received: 14 March 2019 / Accepted: 7 June 2019/Published online: 25 June 2019

(C) The Author(s) 2019

\begin{abstract}
Airborne particulates present a potential hazard to health in a variety of indoor workplaces, from offices to the manufacturing floor. Dust and aerosols are two of the most common occupational risk factors in the workplace worldwide. It is very important to understand when it is sufficient to describe dust exposure only by given mass concentration that dust particles could be in the nanosized range in the workplace air even for brief exposures, such as welding aerosols. The main objective was to assess total dust and nanoparticle concentrations in the selected workplaces and to evaluate their impact on workers' health.
\end{abstract}

\footnotetext{
I. Pavlovska $(\bowtie) \cdot$ Ž. Martinsone $\cdot$ I. Vanadziņš •

I. Mārtiņsone · A. Seile

Institute for Occupational Safety and Environmental Health, Laboratory of Hygiene and Occupational Diseases, Riga Stradins University, 16 Dzirciema Street, Riga LV-1007, Latvia

e-mail: ilona.pavlovska@rsu.lv
}

\section{Ž. Martinsone \\ e-mail: zanna.martinsone@rsu.lv \\ I. Vanadziņš \\ e-mail: ivars.vanadzins@ @rsu.lv \\ I. Mārtinsone \\ e-mail: inese.martinsone@rsu.lv}

A. Seile

e-mail: anita.seile@rsu.lv

\author{
A. Ramata-Stunda \\ In Vitro Testing, INCELL LTD Latvia, 30 Gertrudes Street, \\ Riga LV-1011, Latvia \\ e-mail: anna.ramata-stunda@in-cell.eu
}

This project describes nanoparticle concentrations and their potential impact on workers' health considering the exposure levels in three workplaces. Industrial and non-industrial environments have been included in the project. The office environment was used as an indicator for the background level of comparison with the metalworking and woodworking industries for measurements of dust particles including the nanoscale particles $(>100 \mathrm{~nm})$. Fraction size of the samples according to a dispersity of $>10 \mu \mathrm{m}, 0.25-10 \mu \mathrm{m},<0.25 \mu \mathrm{m}$, and $1-100 \mathrm{~nm}$ was analysed in order to describe the particles' chemical composition at the different stages.

The worst working conditions (the smallest particles, $12 \mathrm{~nm}$ ), the highest total dust concentrations, and the lowest difference between total inhalable particle and nanoparticle concentrations were detected among woodworkers. These findings provide a basis on how to evaluate nanoparticle exposure and its impact on workers' health because the highest immune cell counts and relatively high IL- 6 expression were observed among woodworkers compared with the other groups.

The data show a negative tendency of nanoparticle exposure concentrations on workers' health based on the increase of inflammatory processes and damage to airway epithelial cell functionality.

Keywords Airborne particulate $\cdot$ Aerosol . Occupational exposure $\cdot$ Biological markers $\cdot$ Gene expression $\cdot$ Human health $\cdot$ Nanoparticles 


\section{Introduction}

There are limited data about airborne particulates in occupational environment as described by dust particle size, number, surface area, chemical composition, and their impact on workers' health, especially nanoparticle exposure (O'Shaughnessy 2013; Gao and Lowry 2018; Oomena et al. 2018).

According to previous environmental and occupational air pollution research, nanoparticle exposure negatively influences respiratory, vascular, immune, neural, and other systems. In vivo studies concerning nanoparticles show their ability to be deposed on organs such as the spleen, bones, brain, and lymph nodes (Employers' Confederation of Latvia (LDDK) 2013; Renwick et al. 2001; Takenaka et al. 2001, Nemmar et al. 2002; Oberdörster et al. 2004, 2005; Gilmour et al. 2004; Barlow et al. 2005; Brown et al. 2007). One of the major challenges in (occupational) exposure assessment in the regulatory framework is how to differentiate between natural, incidentally generated nanoscale particles, and manufactured nanomaterials (Draslera et al. 2017).

There are also studies describing the influence of wood dust on cancer development among wood industry workers (Pesch et al. 2008 and Montserrat et al. 2015). Of course, the main occupational route of nanoparticles is inhalation of total dust/ aerosols; however, there is an incomplete description of industries, workplaces, and/or work processes with higher exposure to nanoparticles (Montserrat et al. 2015). There is an assumption that nanoparticles could be an important part of total dust mass, number, and surface area concentration in workplaces involving wood and metal industries during material grinding, polishing, and metal welding processes (at construction sites as well). The upper airways are the first stage where nanoparticles can exert an influence on the human body. Therefore, nasal smears are a good material for the indicative check-up of nanoparticle influences on health status by assessing inflammatory indicators (Glück et al. 2003) in the upper airways (variety of immune cell types and counts) and at the cellular level (epithelial cell and DNA functional damage).

\section{Methods}

Patient and public involvement

Approval was obtained from Ethics Committee of Riga Stradiņš University according to workers' biomaterial data collection and for analysing for scientific purposes. Regarding research protocol, information about project main goals were distributed and individual agreement from each worker was collected during the project.

Thirty-six employees in the age range of 26 to 70 years were included in the current study. Twelve persons were involved from each of the study groups, metalworking and woodworking companies, and office workers as the control group. These groups were selected because the wood and metal industries are the most common industries in Latvia. In total, $42 \%$ of the metalworkers, $25 \%$ of the woodworkers, and $17 \%$ of the office workers smoked. In comparison, regarding gender, $58 \%$ of the workers in the metalworking group were women, $42 \%$ in woodworking, and $33 \%$ in the office group. A certified physician and otolaryngologist evaluated their health condition. Only $8 \%$ of the metalworking and office group employees had high blood pressure, while the woodworking group employees had the high blood pressure in $50 \%$ of cases. The metalworkers and office employees did not have any upper airway diseases, but $8 \%$ of woodworking employees had chronic bronchitis. No specific fitness test was performed but all the workers had undergone general compulsory health examination. Higher workload due to lifting of heavy loads was observed among metal and wood processing workers.

All workplaces had a common ventilation system (it was switched on during measurements) and local ventilation systems were used in woodworking workplaces (not adjustable and built-in equipment tables) and metalworking workplaces (flexible and adjusted according to objects' size). Only stainless steel materials were used in metalworking workplaces, and pine tree materials were used for production in woodworking workplaces during the study, and no specific chemicals (e.g. solvents, varnishes) were used during measurements.

Particle measurement methods

Office environment was selected to assess the background level; metalworking industry (welding) and 
woodworking industry (grinding and polishing) were selected for pilot measurements for dust (includes nanoparticles). Analysis and data from working shift ( $8 \mathrm{~h}$ including breaks) were collected around the breathing zone of the operator. For total dust mass concentration analyses, the specific personal sampling equipment Millipore Nitrocellulose membrane filters $0.025 \mu \mathrm{m}$ VSWP and Gilian 3500 pumps were used. All measurements and calculations were done according to international standard (LVS EN ISO 10882-1:2002) and methods (NIOSH MAM Method 0500).

Did we collect airborne metal particles or measure vaporized metals? Welding fumes were measured, which are a complex mixture of metallic oxides, silicates, and fluorides, and when a metal heated, its vapours condense into very fine particles (solid particulates). Welding fumes generally contain particles from the material being welded, i.e. stainless steel which mainly contains manganese, zinc, chromium, nickel, iron, etc. During the study, stainless steels were welded using MIG welding technic (also known as gas metal arc welding (GMAW) - a process that utilizes a continuously fed solid electrode, shielding gas from an externally supplied source, and electrical power to melt the electrode and deposit this molten material in the weld joint). Particle size distribution was performed automatically by ELPI+ impactor regarding particle size and particle charged value.

The particles collected on aluminium (Al) substrate foils by electrical low-pressure impactor (ELPI+, Dekati Ltd., Finland) with 14-stage cascade impactor were used to analyse occupational air quality based on particle size distribution, number, surface area, and particle mass. The impactor classified particles on so-called stages (stage 1 to stage 14) into 14 fractions by their size in the range from $6 \mathrm{~nm}$ to $10 \mu \mathrm{m}$ with a $9.87-\mathrm{lpm}$ sample flow rate using 40-mbar outlet and 1013.3-mbar inlet pressure. The data saved every second. All ELPI+ measurement files were transferred to EXCEL spreadsheets, using Dekati Ltd. software for ELPI+ data calculation. In this study, we used the total number, surface area, and mass concentrations by size and calculated nanoparticles' number, surface area created by ELPI+, and calculated by ELPI+ software (taking into account calibration adjustment).
Scanning electron microscopy

Scanning electron microscopy (SEM) (NovaNanoSEM 650, Riga Technical University Faculty of Materials Science and Applied Chemistry Institute of Silicate Materials) and energy dispersive X-ray (EDX) analysis were used to provide the elemental analysis or chemical characterization of the dust particles in a low-vacuum field-free mode.

Samples were washed several times in isopropanol, centrifuged, dried, and analysed in a low-vacuum immersion mode operating at a potential of $5 \mathrm{kV}$.

Nasal smear collection and analysis methods

The test materials were smeared on $76 \times 25 \mathrm{~mm}$ microscopy slides. The sample size included 36 slides (12 persons) from each enterprise collected on the first shift day (Monday) and on the fourth shift day (Thursday).

Nasal smear samples were fixed with methanol and stained using different methods:

1. May-Grünwald-Giemsa staining method: allows visualization of epithelial cells, immune cells (eosinophils, neutrophils, mast cells, and lymphocytes), bacterial and fungal hyphae. Samples were stained for 5 min with May-Grünwald solution, then washed with water and stained again for $15 \mathrm{~min}$ with Giemsa solution and rinsed with water.

2. Staining with eosin and methylene blue: samples were stained for $7 \mathrm{~min}$ with eosin solution, then washed with water, stained with methylene blue for $1 \mathrm{~min}$, and washed with water.

All stained samples were visualized at $\times 400$ and $\times$ 1000 magnification using a Leica DMI 4000B microscope, and images were photographed using a built-in digital camera and ImagePro program. During microscopy, each slide was photographed and each cell type on these slides was counted. The different cell types (neutrophils, eosinophils, mast cells, lymphocytes, and epithelial cells) were identified on the microscopic images, and the number of cells was expressed as a percentage of the total number of cells. In addition to various cell types, fungus/mould spores and bacteria (rods and cocci) were also identified on the sample slides of nasal smears. 
Methodology of gene expression analysis in nasal swab samples

The relative gene expression changes were analysed using quantitative real-time reverse transcription polymerase chain reaction (hereinafter, qPCR). In order to determine the particle effects of polluted air on gene expression, RNA was isolated from the nasal swab samples. RNA was isolated by lysing samples using Trizol LS reagent (Invitrogen, USA) according to the manufacturer's recommended protocol. Nasal mucous materials were collected using cytological brushes that allow obtaining more samples directly from the nasal mucous tissues. The sampling brush was then dipped in a special reagent for cell lysis to release the nucleic acid (RNA) for further gene expression analyses which were compared with samples from 15 matched workers who included the following: five volunteers from the offices, five from the wood, and five from the metal industry. The complementary DNA (cDNA) was synthesised using the First Strand cDNA Synthesis Kit (Thermo Scientific, USA) according to the manufacturer's recommended protocol. cDNA was synthesized from 500 ng RNA. The resultant cDNA samples were amplified using a SYBR Green qPCR Master Mix (Thermo Scientific, USA) and detected using an ABI Prism 7300 analyser (Applied Biosystems, USA). The effects on gene expression expressed as relative changes in each gene were analysed and compared with the control (office workers).

\section{Results and discussions}

\section{Dust particle measurements}

The total average dust mass concentrations (also maximum data) were higher during wood grinding/polishing processes and metal welding/grinding processes (Table 1).

The highest concentrations were estimated directly in metal welding and grinding processes (in the nanoscale range) when comparing between wood processing and office (as control or low exposed environment) condition.

The data from the woodworking industry show high levels of particle number concentration in the selected workplaces, and on the other the low surface area. In the same way, the particle number and surface area were detected at low levels in offices.
Scanning electron microscopy

ELPI+ samples (stage/fraction size: $2 / \leq 16.6 \mathrm{~nm}, 3 / \leq$ $27.4 \mathrm{~nm}, 4 / \leq 55.2 \mathrm{~nm}, 5 / \leq 93.6 \mathrm{~nm}, 6 / \leq 262.0 \mathrm{~nm}, 7 / \leq$ $383.0 \mathrm{~nm}, 8 / \leq 614.0 \mathrm{~nm}, 9 / \leq 949.0 \mathrm{~nm}, 10 / \leq 1.60 \mu \mathrm{m}$, $11 / \leq 2.39 \mu \mathrm{m}, 12 / \leq 4.00 \mu \mathrm{m}, 13 / \leq 6.69 \mu \mathrm{m}$, and $14 / \leq$ $9.92 \mu \mathrm{m})$ were analysed by SEM EDX in order to describe the particles' chemical content at different stages (Fig. 1). All of the main inorganic elements constituting the particles were present, including sodium, calcium, silicon, iron, magnesium, manganese, zinc, and chromium, as well as chlorine, potassium, and sulphur. Dust particles comprise all size groups according to the dispersity: visible $(>10 \mu \mathrm{m})$, microscopic $(0.25-$ $10 \mu \mathrm{m})$, ultramicroscopic $(<0.25 \mu \mathrm{m})$, and nanometric (1-100 nm) dust (Pavlovska et al. 2016). Particles from the metal industry samples contain more dust of ultramicroscopic and nanometric sizes and less dust of the microscopic size (both inorganic and organic) already on particles from stage 2. Samples from the woodworking industry contained more microscopic and organic dust for particles with sizes from stage 3 onwards. In samples from the office environment, particles with sizes of less than $27.4 \mathrm{~nm}$ were generally not found.

The predominant elements were carbon and oxygen and there were traces of chlorine and sulphur that possibly originated from organic compounds as well as from inorganic oxides, acids, and salts. For the samples from the office environment, the concentrations of potassium, chlorine, and sulphur did not exceed $1 \mathrm{wt} . \%$. For the samples from the metal industry, chlorine, sulphur, and fluorine contents did not exceed 2 wt.\% in total at all stages. In the samples from the metalworking industry, silica and iron oxide nanoparticles formed the main mass of the samples as their weight percentage (wt.\%) was $98.27 \mathrm{wt} . \%$ of the substrate for nanoparticles ranging from $27.4 \mathrm{~nm}$ (stage 3) to $16.6 \mathrm{~nm}$ (stage 2). Silica and iron oxide accounted for only $5.69 \mathrm{wt} . \%$ of the samples for stage 3 particles $(27.4-16.6 \mathrm{~nm})$ in the woodworking industry, while none of these elements were found in stage 2 .

In the office environment, no particular elements were found in samples in the size range of 27.4$16.6 \mathrm{~nm}$, and they did not exceed $13.17 \% \mathrm{wt} . \%$ of the area chosen for analysis in total at all stages.

Otherwise, the samples from workplaces in both woodworking and metalworking industries also contained manganese ( $\leq 6 \mathrm{wt} . \%$ and $\leq 2 \mathrm{wt} . \%$, respectively) for stage 3 and stage 4 and potassium, chlorine, and sulphur, which 


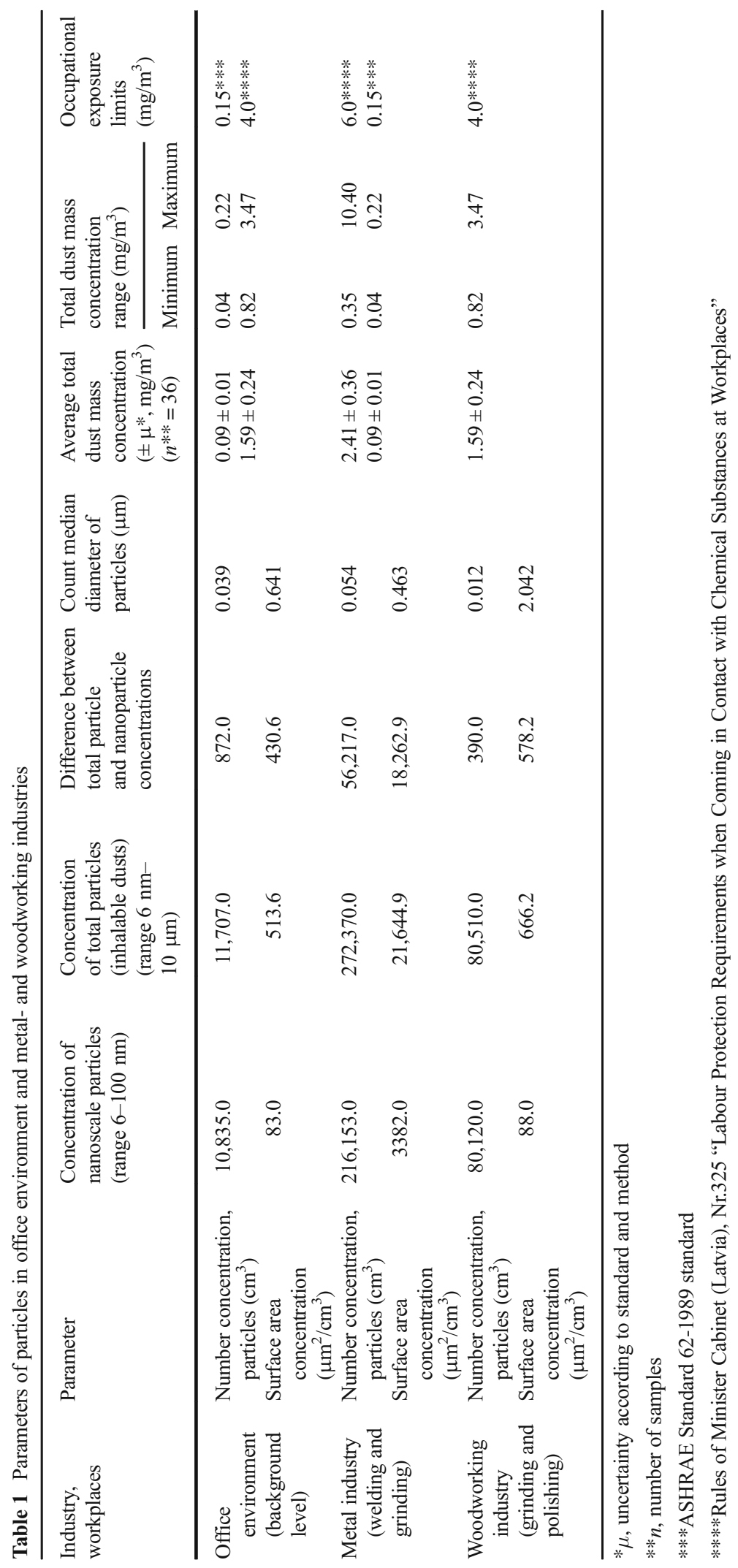




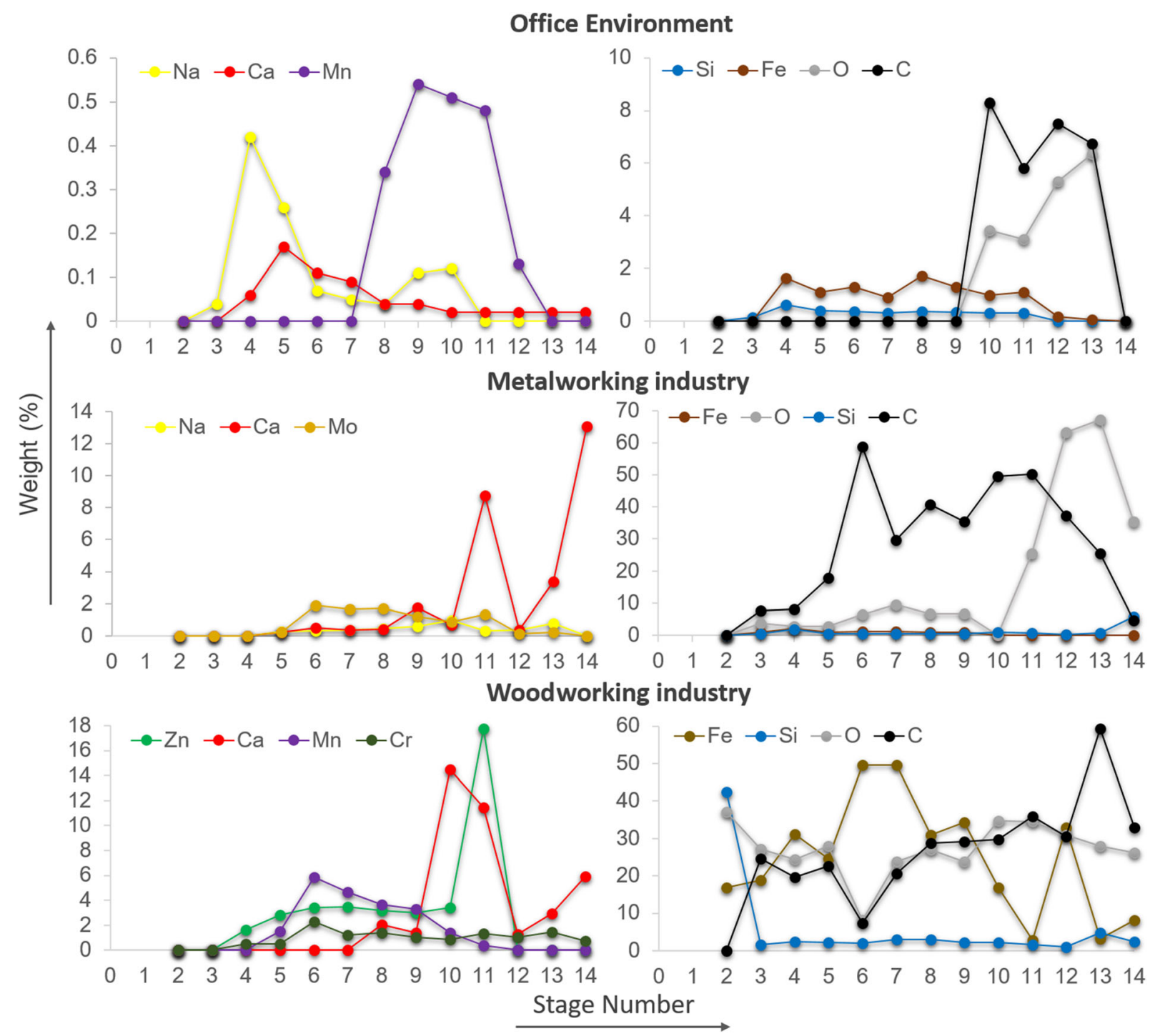

Fig. 1 The average results of elements in the office, metalworking industry, and woodworking industry

did not exceed $1 \mathrm{wt} . \%$ at all stages with the exception of stage 14 (K 11 wt.\%, Cl 11 wt.\%, S 5 wt.\%).

Office nasal lavage samples contained several cells in a $20-\mu \mathrm{m}$ (to $200-\mu \mathrm{m}$ ) scanned area, or did not contain any at all. In contrast, metal and woodwork processing samples contained a variety of cell types in all probes before and after the shifts.

Figure $2 \mathrm{~b}$ shows the cell uptake (up to $60 \mathrm{~nm}$ ) with nanoparticles, which coincides very well with the particle size in the air. There are mostly spherical silica particles with different dimensions of $<50 \mathrm{~nm}$, 50-130 nm, and $130-370 \mathrm{~nm} ; \mathrm{Fe}_{2} \mathrm{O}_{3}$ and $\mathrm{ZnO}$ nanoparticles $<30 \mathrm{~nm}$ from the elemental overlay (Kurjane et al. 2017).
Results of nasal smears

The nasal smear results show that the immune cell count is lowest among the office workers for all analysed cell types. The nasal smear results of the first day shift (on Monday) between the different working environments were compared in Fig. 3, which shows that neutrophils dominated all workers' nasal smears. The lowest proportion of neutrophils in the nasal smears was detected among office workers. The highest proportions of neutrophils were detected among the metal and wood industry workers, which were 1.56 and 1.92 times higher, respectively, than that in the 


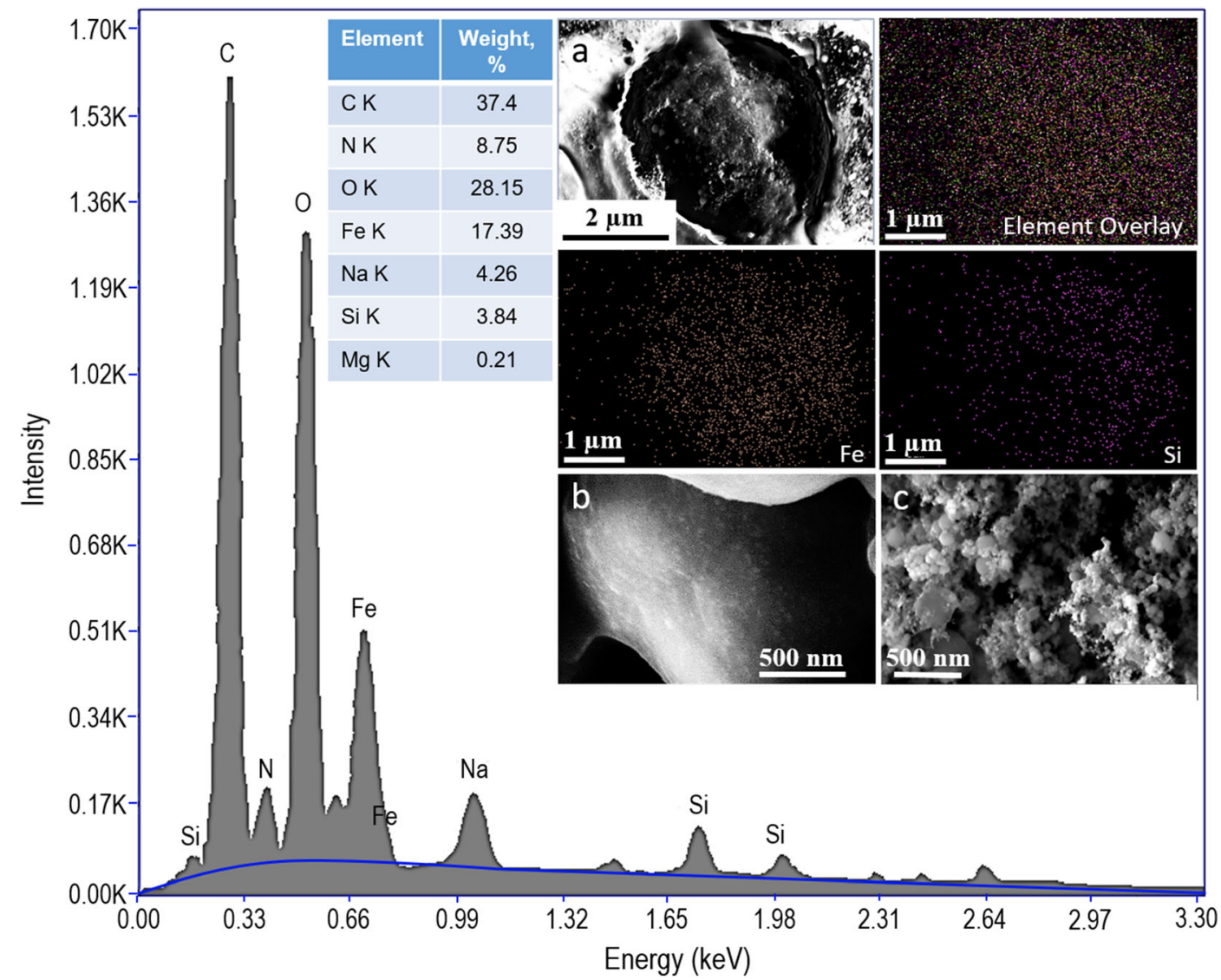

Fig. 2 Nova NanoSEM 650 EDX results of human epithelial cell uptake with nanoparticles for metallurgy workers at stage 6 after the shift: a live map image, $\mathbf{b}$ cell uptake with nanoparticles, and $\mathbf{c}$ particles from the filter

office workers' group. The wood industry workers' smears also contained a relatively higher number of lymphocytes, while the highest proportion of eosinophils was observed among metal industry workers on the first working day of the week (Fig. 3).

\section{Cell populations on \\ Day 1}

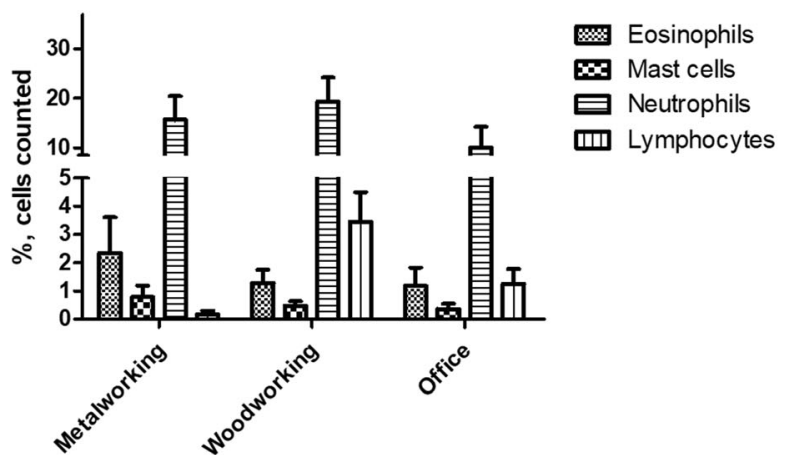

Cell populations on

Day 2

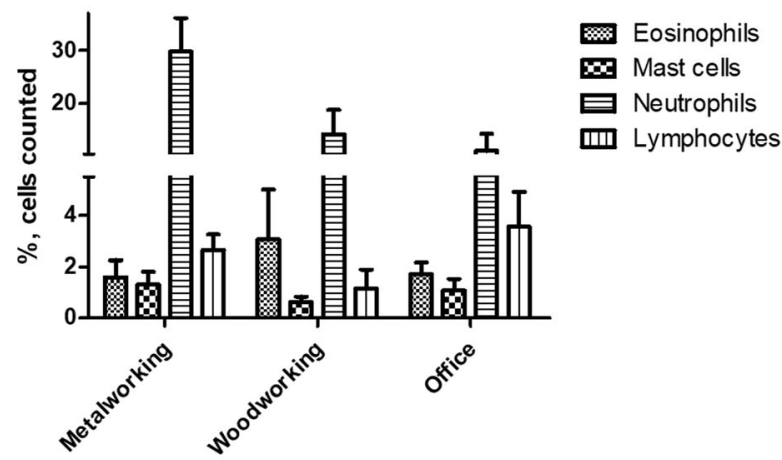

Fig. 3 Cell types identified in nasal smears of workers $(n=36)$ of different working environments and changes of cell counts (percentage of the total cell count) during the working week 
Results of caspase 3, gelsolin genes, and interleukin 6 expression

Caspase 3 (CASP-3) activity could be related with the chemical composition of the particles. There are some metals, especially zinc, which can provide inhibition of all involved factors along caspase signals' pathways. Caspases are a class of cysteine proteases that are mainly divided into two groups according to their functions in apoptosis and inflammation. Caspase cascades play crucial roles in apoptosis and are highly associated with cancer development and prognosis. However, the role of expression and activation of various caspases in tumorigenesis remains a double-edged sword. Low expression levels or inactivation of caspases frequently occur in cancer cells and make the cells resistant to microenvironmental stresses and treatments. Conversely, the overexpression of caspases in dying cells may release growth-stimulating signals to allow the non-apoptotic tumour cells to proliferate and survive under stress conditions (Liu et al. 2017).

CASP-3, gelsolin (GSN), and interleukin 6 (IL-6) expression compared with the control group are shown in Fig. 4. All three of these genes (GSN, IL-6, and CASP-3) are more suppressed among metal industry workers compared with the other groups. It should be noted that IL- 6 expression in all the three groups was detected close to the total average level of the control group. The most pronounced was GSN gene suppression among all three groups. Caspase-3 gene expression was suppressed in the nasal mucosa material of the metal industry workers, while it increased in wood industry workers. A relatively high IL-6 expression was detected among wood processing workers compared with that of the control group.

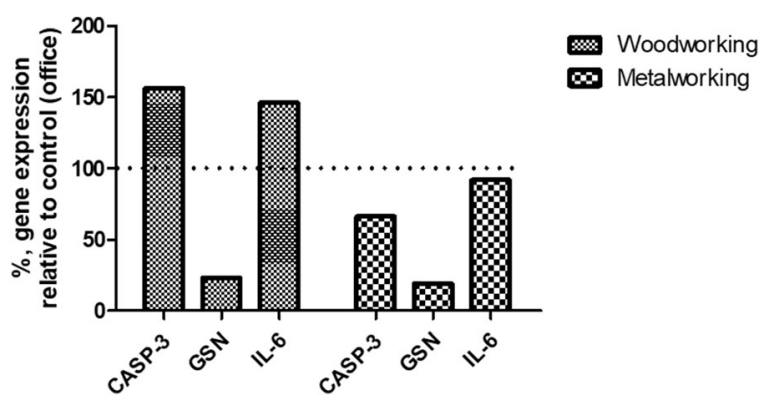

Fig. 4 Relative changes in gene expression in nasal tissues of woodworking and metalworking employees compared with the control group (office employees). The dashed line indicates the gene expression level of the control group (100\%)
The total dust mass concentrations did not exceed acceptable levels in the tested occupational environments. The maximum (peak) concentrations in the wood industry workplace were high but they scored as acceptable. The same results were obtained for the metal welding and grinding processes in which the maximum concentrations were close to acceptable levels. In general, total mass concentrations did not exceed any occupational exposure limits. In contrast, particle number concentrations were extremely high during the welding and metal grinding processes $\left(272,370\right.$ particles $\left./ \mathrm{cm}^{3}\right)$ with a median diameter of particles of $0.054 \mu \mathrm{m}$. Similar results were obtained during the wood grinding and polishing processes, where particle number concentrations were almost four times lesser than those during the welding and metal grinding processes, but still had high concentrations $\left(80,510\right.$ particles $\left./ \mathrm{cm}^{3}\right)$ compared with office air pollution level. The detected median diameter of particles and difference between total particle and nanoparticle concentrations during woodworking processes could be used to evaluate the nanoparticle impact on workers' health. The particle surface area showed the same tendency as the particle number concentrations: the highest concentrations were detected during the welding and metal grinding processes. Similar particle surface areas were detected in the woodworking and office environments. However, the detected median diameter of particles during surface area measurements was $2.04 \mu \mathrm{m}$ during the woodworking processes and $641 \mathrm{~nm}$ in the office environment, the latter of which is microscale and not nanoscale. In order to evaluate the impact of nanoparticle exposure on workers' health, at least three parameters must be considered together: the particle mass, number, and surface area concentrations (O'Shaughnessy 2013). The workers' health status data showed an increased number of lymphocytes in the group of office workers. The most significant increase was in the number of neutrophils in the nasal smears of the metal industry workers; however, eosinophil counts were also high among the wood industry workers. While gene expression results showed gelsolin gene suppression, there were increases in expression of the caspase 3 and IL-6 genes, which together have a negative effect on the workers' health status. GSN plays an important role in moving cells including cilium formation which is responsible for providing clearance of harmful physical factors (e.g. dust) from the respiratory tract after inhalation. Gelsolin inhibits cell mortality or apoptosis through the specific inhibition of cytochrome $\mathrm{C}$ release in cells. 
Animal experiments with mice have shown that a reduced amount of GSN increases the permeability of the pulmonary vascular barrier, thus increasing the risk of lung infections (Becker et al. 2003). Therefore, gelsolin gene suppression may be indicating adverse effects by the long-term air pollution of the working environment on the functionality of the respiratory epithelium. The different effects on the expression of the CASP-3 gene are associated with particulate air pollutants of varying chemical compositions in the particular working environments (wood dusts, welding aerosol, and ambient air). The increase in CASP-3 gene expression may be viewed as a negative aspect because animal experiments show an association between CASP-3 expression and lung cell apoptosis (Bai and Meng 2010). IL-6 acts both as an inflammatory cytokine and as a mediator in various regeneration processes. IL- 6 secretion was described in cases of airway inflammation characterized by the infiltration of eosinophils and neutrophils. IL-6 levels increase in asthma sufferers (Chu et al. 2015; Kuhlbusch et al. 2018; Rincon and Irvin 2012). Therefore, the relatively high proportion of neutrophils may explain the higher IL-6 expression observed in wood processing workers and eosinophils in their nasal smear samples. Perhaps the induction of gene expression in the nasal mucosa samples among wood processing workers suggests a higher inflammatory process compared with the two other worker groups.

In the future, there is a need to provide research studies evaluating the neurological health effects among workers who are exposed to high nanoparticle concentrations because in vivo studies show nanoparticles are transported through the nasal nerves to the animal (rat) brain. Inhaled nanoparticles damage airways' epithelial cells and are to a significant extent translocated to the central nervous system (CNS), and the potential longterm effects of their accumulation in the olfactory bulb and translocation of the CNS are new fields of studies as well (Oberdörster et al. 2005).

Such studies are particularly important in cases of exposure to welding aerosol, which contains fumes of a toxic chemical composition (Feikert et al. 2004) including manganese, zinc, aluminium, copper, and metals.

\section{Conclusion}

The smallest detected median diameter of particles (12 $\mathrm{nm})$ and the smallest difference between inhalable dust and nanosized particle number concentrations are observed in the occupational air of wood industry workplaces. Consistently, the wood processing workers' health status showed higher inflammatory indicators, such as a relatively high proportion of neutrophils and eosinophils in nasal smear samples and the induction of IL-6 gene expression in the nasal mucosa samples.

The total mass concentration did not exceed any of the occupational exposure limits for the metalworking industry, but particle number concentrations were extremely high during the welding and metal grinding processes with nanosized median particle diameters detected in number concentration measurements. The metalworkers' health status showed increased immune cell counts after four working shift days, but gene expression levels among the metal industry workers were similar to those of the office workers. Consequently, the data show a negative tendency of nanoparticle exposure concentrations on workers' health status based on the increase of inflammatory processes and damage to airway epithelial cell functionality. Furthermore, inhalation is considered to be the primary route of exposure for dust with the smaller particles having the potential for greater effects on human health as they reach alveolar level and could lead to a wide range of negative health effects such as respiratory diseases, acute toxic effects, allergic reactions, and cancers.

The respiration system is a direct pathway for nanoparticles to CNS. This pathway from the nasal mucosa to CNS could be important in inducing neurotoxic effects following acute or chronic environment or occupational inhalation of nanoparticles and long-term effects of their accumulation are a new area of research.

Acknowledgements We would like to thank INCELL LTD researchers' team for consultation and technical support.

Funding information This work was supported by ESF project "The development of up-to-date diagnostic and research methods for the risks caused by nanoparticles and ergonomic factors at workplaces" (Agreement No. 2013/0050/1DP/1.1.1.2.0/13/ APIA/VIAA/025).

\section{Compliance with ethical standards}

Conflict of interest The authors declare that they have no conflict of interest. 
Open Access This article is distributed under the terms of the Creative Commons Attribution 4.0 International License (http:// creativecommons.org/licenses/by/4.0/), which permits unrestricted use, distribution, and reproduction in any medium, provided you give appropriate credit to the original author(s) and the source, provide a link to the Creative Commons license, and indicate if changes were made.

\section{References}

Bai J, Meng Z (2010) Expression of caspase and apoptotic signal pathway induced by sulfur dioxide. Environ Mol Mutagen 51(2):112-122

Barlow PG, Clouter Baker A, Donaldson K, McCollum J, Stone V (2005) Carbon black nanoparticles induce type II epithelial cells to release chemotoxins for alveolar macrophages. Part Fibre Toxicol 2:1-14

Becker PM, Kazi AA, Wadgaonkar R, Pearse DB, Kwiatkowski D, Garcia JG, Rincon M, Irvin CG (2003) Role of IL-6 in asthma and other inflammatory pulmonary vascular permeability and ischemic injury in gelsolin-deficient mice. Am J Respir Cell Mol Biol 28(4):478-484

Brown DM, Kinloch IA, Bangert U, Windle AH, Walter DM, Walker GS, Scotchford CA, Donaldson K, Stone V (2007) An in vitro study of the potential of carbon nanotubes and nanofibers to induce inflammatory mediators and frustrated phagocytosis. Carbon 48(9):1743-1756

Chu DK, Al-Garawi A, Llop-Guevara A, Pillai RA, Radford K, Shen P, Jordana M (2015) Therapeutic potential of anti-IL-6 therapies for granulocytic airway inflammation in asthma. Allergy Asthma Clin Immunol 11(1):14

Draslera B, Sayreb P, Steinhäuserc KG, Petri-Finka A, RothenRutishausera B (2017) In vitro approaches to assess the hazard of nanomaterials. NanoImpact 8:99-116

Employers' Confederation of Latvia (LDDK) (2013) Working conditions and risks in Latvia 2012-2013. RSU, Riga, p. 139, ISBN 978-9984-793-41-2

Feikert T., Mercer P., Corson N., Gelein R., Opanashuk L., Elder A., Silva V., Carter J., Maynard A., Finkelstein J. and Oberdorster G.: Inhaled solid ultrafine particles (UFP) are efficiently translocated via neuronal nasal-olfactory pathways. Toxicologist, 78 (Suppl. 1), 435-436 (2004)

Gilmour PS, Ziesenis A, Morrison ER, Vickers MA, Drost EM, Ford I, Karg E, Mossa C, Schroeppel A, Ferron GA, Heyder J, Greaves M, MacNee W, Donaldson K (2004) Pulmonary and systemic effects of short-term inhalation exposure to ultrafine carbon black particles. Toxicol Appl Pharmacol 195:35-44

Glück U, Schutz R, Gebbers JO (2003) Cytopathology of the nasal mucosa in chronic exposure to diesel engine emission: a fiveyear survey of Swiss customs officers. Environ Health Perspect 111:925-929

Kurjane N, Zvagule T, Martinsone I, Vanadzins I, Pavlovska I (2017) The effect of different workplace nanoparticles on the immune systems of employees. J Nanopart Res 19(9):320

Liu P.F, Hu Y.C, Kang B.H, Tseng Y.K, Wu P.C, Liang C.C, et al. 2017 Expression levels of cleaved caspase-3 and caspase-3 in tumorigenesis and prognosis of oral tongue squamous cell carcinoma. PLoS ONE 12(7): e0180620. https://doi. org/10.1371/journal.pone.0180620

Montserrat AS, Chamorro AJ, Hernández-García I, Iglesias-deSena H, Martín-Rodero H, Herrera C, Marcos M, MirónCanelo JA (2015) Association between occupational exposure to wood dust and cancer: a systematic review and metaanalysis. PLoS One 10(7):e0133024

Nemmar A, Hoet PHM, Vanquickenborne B, Dinsdale D, Thomeer M, Hoylaerts MF, Vanbilloen H, Mortelmans L, Nemery B (2002) Passage of inhaled particles into the blood circulation in humans. Circulation. 105:411-414

O'Shaughnessy PT (2013) Occupational health risk to nanoparticulate exposure. Environ Sci Processes Impacts 15:49-62

Oberdörster G, Oberdörster E, Oberdörster J (2005) Nanotoxicology: an emerging discipline evolving from studies of ultrafine particles. Environ Health Perspect 113:823839

Oberdörster G, Sharp Z, Atudorei V, Elder A, Gelein R, Kreyling W, Cox C (2004) Translocation of inhaled ultrafine particles to the brain. Inhal Toxicol 16(6/7):437-445

Oomena AG, Steinhäuserb KG, Bleekera EAJ, van Broekhuizena F, Sipsa A, Dekkersa S, Wijnhovena SWP, Sayre PG (2018) Risk assessment frameworks for nanomaterials: scope, link to regulations, applicability, and outline for future directions in view of needed increase in efficiency. NanoImpact 9:1-13

Pavlovska I, Martinsone Z, Vanadzins I, Martinsone I, Seile A, Sudmalis P (2016) Occupational exposure parameters for characterization of nanoparticulate matter toxicity: metal versus wood processing. Process Saf Environ Prot 102:230-237

Pesch B, Pierl CB, Gebel M, Gross I, Becker D, Johnen G, Rihs HP, Donhuijsen K, Lepentsiotis V, Meier M, Schulze J, Brüning T (2008) Occupational risks for adenocarcinoma of the nasal cavity and paranasal sinuses in the German wood industry. Occup Environ Med 65(3):191-196

Renwick LC, Donaldson K, Clouter A (2001) Impairment of alveolar macrophage phagocytosis by ultrafine particles. Toxicol Appl Pharmacol 172(2):119-127

Rincon M, Irvin CG (2012) Role of IL-6 in asthma and other inflammatory pulmonary diseases. Int J Biol Sci 8(9):12811290

Takenaka S, Karg E, Roth C, Schulz H, Ziesenis A, Heinzmann U, Schramel P, Heyder J (2001) Pulmonary and systemic distribution of inhaled ultrafine silver particles in rats. Environ Health Perspect 109(4):547-551

Kuhlbusch TAJ, Wijnhoven SWP, Haase A (2018) Nanomaterial exposures for worker, consumer and the general public. NanoImpact 10:11-25

Gao X, Lowry GV (2018) Progress towards standardized and validated characterizations for measuring physicochemical properties of manufactured nanomaterials relevant to nano health and safety risks. NanoImpact 9:14-30

Publisher's note Springer Nature remains neutral with regard to jurisdictional claims in published maps and institutional affiliations. 